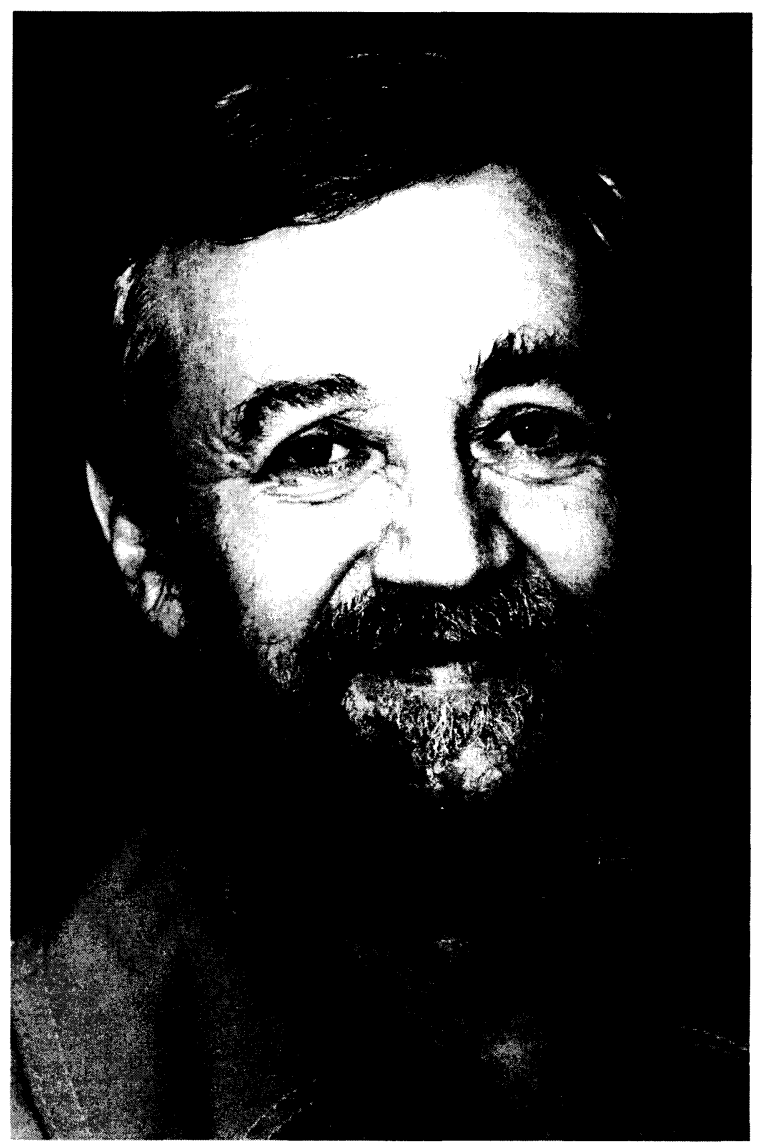

Ebbe Kløvedal Reich

7/3 1940 - 23/4 2005

(foto: Frank Bøgh) 


\title{
Ebbe Kløvedal Reich in memoriam
}

\author{
Af Johs. H. Christensen
}

I en tid, hvor fortællingen, den gode historie, stort set er fordrevet fra litteraturen, var han en fortæller, der tog vare på traditionen fra Ingemann og forvaltede den i fornyelse og en form, der svarede til hans egen tid. Derfor, akkurat derfor blev han aldrig rigtigt anerkendt som digter. Mens et utal af snøftende lyrikere, ophavsmænd til fem eller seks magre digtsamlinger, er blevet belønnet med akademiets store pris, gik den aldrig til Ebbe Reich, skønt hans forfatterskab folder sig ud i talrige genrer og fylder en hel reolmeter.

Blev han ikke anerkendt af kollegerne, så blev han det af læserne, af folket. Han må høre til de sidste fyrre års mest læste danske forfattere, for han skrev historie og historiske fortællinger: Halvfems historier fra Danmarkshistorien blev det til - fordelt over tre bind (1981-83). En række store danmarkshistoriske romaner blev det til: Rejsen til Messias i tre bind (1974), Fa og frande (1977), Festen for Cacilie (1978), En engels vinger (1990). For nu kun at nævne nogle af dem, ikke de bedste - for de er alle de bedste. Skulle jeg træffe det umulige valg, faldt det på Rejsen til Messias, hvis fortælleglæde stadig kan sætte sig som en varm snurren i min læsersjæl. Siden kom så den vidtløftige og intense, krimiagtige Zenobias liv (1998), der åbner det europæiske perspektiv både vertikalt og horisontalt, og til sidst, allersidst den vildt fabulerende, kosmisk besatte Himlene og Jorden på over 600 sider og med en vrimlende mangfoldighed af indfald - lige fra kirkehistoriske dramaer og svinestreger i det gamle Alexandria til science-fiction-indbrud og politiske rævekager i Danmark. En kraftpræstation, hvis dybder slet ikke er loddet endnu, og en bevægende og stærk digtning, fordi den blev til samtidig med forfatterens fremadskridende sygdom.

Gennembruddet kom med Frederik. En folkebog om N. F.S. Grundtvigs tid og liv (1972), det år, vi stemte os ind i EF. Det er hans bedst solgte og mest læste bog. Den er kommet i fjerde udgave og i utallige oplag - også som billigbog.

Jeg havde altid været fascineret af forfatteren - lige fra essaysamlingen Svampens tid (1969) med dens blanding af reportager, taler, kommentarer og en dem forbindende tekst, som gjorde den til en slags litterær selvbiografi - litterær i den forstand, at den ikke rummede noget om forfatterens barndom, forældre, forelskelser og den slags, 
men handlede om hans iagttagelser og manøvreringer i det offentlige rum og $\mathrm{i}$ den subkultur, der $\mathrm{i}$ de år skød op og satte store spraglede blomster. Genren blev taget op igen i hans sidste bog, men her i en anden version: De såkaldte Grundtvig-inspirerede "Mands Minde"foredrag: Efter krigen - før freden (2004)

Det hænder - måske to tre gange i ens liv - at man får en bog i hånden. En særlig bog. Først skaber den kaos, et saligt kaos, så møblerer den hele ens åndelige bevidsthed om. Akkurat den rigtige bog på akkurat det rigtige tidspunkt. Sådan gik det mig med Frederik, der åbnede mig vejen til Grundtvigs person, biografi - og vigtigst forfatterskab, som jeg pludselig kunne læse i lyset af hans mytologiske væsen, sådan som det pejles og skildres i Frederik - så levende, som var man samtidig med hovedpersonen. I ingen anden bog om Grundtvig, jeg kender, ånder hans væsen, hans lidenskab, hans syner, hans længsel, hans visioner, hans tro så befriet som her. Ebbe Reichs bog blev min tilskyndelse til en fordybelse i Grundtvigs liv og digtning, som har varet lige siden og vil fortsætte til mine dages ende.

Ebbe Reich vendte tilbage til "Den Gamle", hvis hele person lever som en nærende understrøm i hans samlede produktion og livsforståelse, med den smukke, lavmælte og afklarede Solskin og lyn Grundtvig og hans sang til livet (2000), som må være den allerbedste elementære introduktion til, hvem Grundtvig var, hvad han foretog sig, og hvad han ville.

Bogen står som et glædeslysende og fortrøstningsfuldt supplement til de tre bøger, Ebbe Reich skrev om kristendommens ytringer i kirken (Drag ind ad disse porte - 14 beretninger om kirkerne $i$ den indre by (1996)), i menigheden (Kun et gaestekammer. Historien om den danske folkekirkes fødsel (1999)) og i troen. Bogen om kirkens og menneskers billeder af den Jesus, som aldrig kan fastholdes. Derfor finder vi ham kun i mødet med skiftende tiders billeder, som nok udtrykker hans guddommelighed og menneskelighed, men brudt gennem vekslende fortolkningers og det menneskelige oplevelsesberedskabs prismer (Billeder af Jesus. En beretning fra Danmarkshistorien (2001)).

Gennem hele Ebbe Reichs liv og virksomhed går der en ubændig længsel efter et fællesskab af frie, ligeværdige mennesker, en længsel, han fandt besvaret hos Grundtvig og omsat til en konkret utopi med et solidt remtræk til virkeligheden. Derfor kunne han citere to udsagn om Grundtvig fra folk, der ikke hørte til den bagstræveriske og bredbagede grundtvigianisme, som $\mathrm{i}$ dag er totalt forsumpet (Plan B), nemlig Hørup og Andersen Nexø.

Hørup sagde: "Som politisk profet var Grundtvig af de små, for det han skabte, var uden skel og grænse". 
Nexø sagde: "Bonden kan løfte blikket og løfte det ud af den klæge masse, hvor brødet bliver til. Og det skylder han først og fremmest en skare mænd med Grundtvig i spidsen. De tog ham broderligt ved hånden og sagde: $\mathrm{Du}$ er et menneske! - Hele tilværelsens vidunder i ét! Se dig ud!"

For egen regning føjer Ebbe Reich så til: "Det, Grundtvig udrettede, var ganske rigtigt uden skel og grænse, og derfor på en måde ikke politik, men set på en anden måde skabte det almue om til folk - med en mangfoldighed af politiske virkninger".

I grunden var hans egen lidenskab - i lighed med Grundtvigs hverken politisk eller videnskabelig (han studerede historie, men uden nogen side at afslutte studiet blev han en fremragende historiker). Hans lidenskab var poetisk - som Grundtvigs. Ud af hans poetiske temperament - poetisk i ordets videste betydning: skabende, opdagende, eksperimenterende, undersøgende - sprang hans forfatterskab, hans politiske aktivitet - kampen mod EF, Vietnam-krig og markedsøkonomisk grådighed.

I en tid, hvor overtro og plattenslageri, navlepillere og selvsuttere forpester den religiøse og kirkelige debat (læs bare en kronik af en af biskopperne!), ville Ebbe Reich med Grundtvig fastholde både troen og mysteriet. En jævn, enfoldig kristen tro på syndernes forladelse, en tro, der, når den blev af sin grublen træt, hvilede sig ved Fadervor at bede; en tro, der kunne finde udtryk og ro i for eksempel ord som disse: "Verden siger, det er tant, / hjertet føler, det er sandt, / at til støv er dalet ned, / livet i Guds kærlighed".

Samtidig stod den erfaring fast, at verden er dyb og mangfoldig og mystisk og Guds veje uransagelige, så at han kommer til os i oplevelser og syner (Ebbe Reich kendte den slags af egen erfaring - både med og uden brug af euforiserende stoffer). Som når Grundtvig så "i Aanden Vorherre Jesus Kristus vandre giennem sine syv Menigheder paa Jorden, ligesom han beskrives i Aabenbarings-Bogen, som en guddommelig Menneske-Søn med en Røst og med mange Stjerner i sin Haand". . . Da er det - af hensyn til virkelighedsforankringen vigtigt at kunne fremsige bekendelsens ord, som gør det klart, hvad du har at holde dig til og bedre end nogen kan passe troens hygiejne.

I en tid, hvor medier - tv især - gør kloden lille og den lokale verden til en uddød provins, hvor brug-og-smid-væk holdningen gør det, som havde værdi $\mathrm{i}$ går til flitterstads $\mathrm{i}$ morgen, så at kynismen og ligegyldigheden dagligt øges - mellem mennesker indbyrdes og $\mathrm{i}$ samfundet som helhed - ville Ebbe Reich fastholde det folkelige fællesskab og et grundlæggende syn på samfundet som en demokratisk sammenslutning af frie, ligeværdige, ansvarsbevidste mennesker. Herom handler i virkeligheden hans romaner, hans syv essay- 
samlinger og hele hans politiske og folkelige aktivitet i Christiania, på højskoler, i kollektiver og i græsrodsbevægelser, ja hans hele liv. Han ville - som sin store læremester Grundtvig - knytte sig til alt, hvad der i samtiden "spaaede en bedre og lykkeligere Fremtid for Folk, som de er flest og for den underfulde Udvikling og klare Oplysning af vor dybe, vidunderlige Natur, som aabenbar er Skaberens Vilje og Menneske-Aandens Drift". ${ }^{2}$ Og som fă andre siden den store generation af højskolefolk lykkedes forehavendet for ham - trods hans alt for korte liv.

I en tid, hvor det danske sprog forfladiges og forurenes med hæsligheder som "fuck", "event" "pay-off", "branding", "manage ment" og mange andre platheder, skrev Ebbe Reich det smukkeste, mest melodiske, mest underfundige og mundrette dansk, et dansk, der var lysvågent for alt stort og skønt hernede og kunne spejle det alt sammen, så at hans sprog blev båret af sans for humor og underskruet ironi, for smil gennem tårer, men også af den ægte vrede.

\section{Noter}

${ }^{1}$ P. G. Lindhardt (red.) (1977), Regeneration. Grundtvigs Pradikener $i$ Kirkeåret 1855-56.

${ }^{2}$ Citeret efter Kaj Thaning (1971), For menneskelivets skyld. Grundtvigs opgør med sig selv. 